\title{
Sisterly Bond/Sisters of Agony: A Feminist Reading of Beth Henley's Crimes of the Heart and Ntozake Shange's for Colored Girls Who Have Considered Suicide / When the Rainbow Is Enuf
}

\author{
Amal Gouda Abdel Aziz ${ }^{1}$ \\ ${ }^{1}$ Unaizah College of Sciences and Arts, Qassim University, Kingdom of Saudi Arabia \\ Correspondence: Amal Gouda Abdel Aziz, Department of English Language, Unaizah College of Sciences and \\ Arts, Qassim University, Kingdom of Saudi Arabia.
}

Received: February 17, 2018 Accepted: March 19, 2018 Online Published: May 14, 2018

doi:10.5539/ells.v8n2p52ＵRL: https://doi.org/10.5539/ells.v8n2p52

\begin{abstract}
Beth Henley (1952- ) and Ntozake Shange (1948- ) are renowned U.S. women playwrights. Exploring into the feminist insights of these contemporary writers, this paper will attempt to demonstrate that though their most celebrated plays, Crimes of the Heart and for colored girls, display noticeable dissimilarities in the structure, tone and technique, yet they are also characterized by parallel feminist visions with regard to women's suffering in a predominantly patriarchal society. Both plays revolve around the painful experiences of women who have been subordinated by a male-dominated culture. In their struggle to find new positive images of self, these women endeavor to redefine the meaning of their humanity and to create invigorating images of the future. Rejecting conventions and rising above suffering and silence, they find their redemption in a mystical sense of feminine unity, a sisterly bond of love and care among women to transcend the degenerate forces, which have long subjugated and banished them.
\end{abstract}

Keywords: Crimes of the Heart, for colored girls, women's suffering, sisterly bond

\section{Introduction}

In spite of the disparity of their dramaturgy, Beth Henley's Crimes of the Heart (1979) and Ntozake Shange's for colored girls who have considered suicide / when the rainbow is enuf (1974) have much in common and are distinguished by similar feminist views. Each play immediately established its writer as a major voice in modern American theatre. Both plays were produced off-Broadway, won prestigious prizes (a Pulitzer for Henley and an Obie for Shange) and later had many successful Broadway runs. Both made immediate successes for promising women playwrights and aroused controversial debates among feminist critics. Both plays deal with relationships among women who have led troubled lives and are in desperate quest of solutions to their pressing problems, attempting at the same time to redefine their existence and hopefully to develop an alternate vision of the future. Both plays deal with the suffering women who have been badly manipulated by men who are not part of the dramatic action on the stage. These women have to recognize that their subordination is not predestined by nature, but is societally enforced before they are able to better their conditions and achieve their salvation through a sense of feminine unity - a bond of sympathy and compassion among the tormented women to surmount the dehumanizing powers that have long oppressed them and caused their misery and despair. Both plays are concerned with issues of family and community and examine the origins of domestic abuse suggesting the high costs women have to pay to find their identities as fully independent creatures. Moreover, both plays end with a scene offering women a glimpse of hope for survival through love, care and companionship with other women.

\section{Method}

The paper starts by examining the distinct dramatic techniques of the two plays then moves into discussing each play in order to highlight the parallel feminist visions of both authors. The study is a comparative, descriptive-analytical one.

\section{Discussion}

\subsection{A Note on the Two Plays' Dramatic Techniques}

Beth Henley chooses the form of comedy to examine the challenges of white women who do not fit in the 
traditional patriarchal society of southern United States. Her work adeptly mingles solemn, life-threatening issues with ordinary daily activities. According to Demastes (1986), what distinguishes her comic art is that the serious concerns "are reduced to trivialities, and the mundane is raised to absurd but believable levels of importance" ( $p$. 235). By populating her family drama with bizarre characters, she has combined "the conventions of the naturalistic play with protagonists of absurdist comedy" (p. 237). Gupton (2002) notes that Henley skillfully probes into the possibility of comedy as an upsetting transformative challenge to the status quo not only temporarily but constantly. In addition, this genre can channel anger and rebellion of women who seek to break free of traditional roles and re-define themselves in southern society. Laughter filled with sympathy is a means for women's resistance in the play; one that enables these loners to endure the isolation, fragility and defeat that otherwise would destroy them. Consequently, instead of using the traditional comic form as a social preservative that keeps societal outsiders within the confines of appropriate conduct, Henley reorganizes it to suite her thematic and structural purposes. As Gupton (2002) puts it, she modifies the comic narrative structure to supply her protagonists with alternative outcomes and to avoid the familiar happy conclusion leaving her characters with an existential recognition rather than with an orderly pleasing finale.

Ntozake Shange, on the other hand, confronts the Euro-American ideals and violates the standard structures of drama as a genre altogether by introducing a totally new dramatic form in which the spoken and chanted words harmonize with body language to produce an integrated concord which articulates black women's struggle against racial and sexual oppression. She calls her project "a chreopoem" that combines dance, jazz and blues with stories delivered in a provocative but also poetic Afro-American vernacular-all of which relate to her African heritage rather than to Euro-based traditions. Shange (1979) asserts in one of her essays, "uncovered losses/ black theatre traditions," that the form of the conventional well-made play is too limiting and unable to express black culture and sensibility (p. 7). She further maintains, "as a poet in American theater/ I find most activity that takes place on our stages overwhelmingly shallow/silted and imitative. That is probably one reason I insist on calling myself a poet or writer/ rather than a playwright" (p. 7). To classify herself as a playwright would confine her to what she believes to be "the same artificial aesthetic that plague our white counterparts/ "the perfect play" (p. 7). By rejecting the models of conventional theatre, she abandons plot and characterization, instead presenting short-lived performers/characters who tell narratives about themselves and other black women disclosing the agony and difficulty of being black female in America.

Regardless of obvious differences in their dramatic techniques, both dramatists utilize the device of storytelling to enable their women to communicate their sufferings, fears and hopes to other women and to the audience. Their revealing talks tend to back up Spender's observation in her Man Made Language (as cited in Laughlin, 1986) that when women begin to talk to one other, the image of male hegemony is in danger since many men are exposed and the feeble veneer of male pre-eminence is laid bare. In Henley's Crimes of the Heart, the three Magrath sisters reveal much about their tragic past by recalling the agonizing old stories in conversation. Their family history is one of evasion, pain and sorrow, which makes them incapable of facing life's hardships or taking part in life. Shange's for colored girls consists of poetic episodes, in which the women tell and perform their stories of abuse and suffering.

\subsection{Crimes of the Heart}

The title of Henley's play suggests various readings. The play contains some crimes in the realistic sense: Zackery's abuse of Babe, Babe's shooting Zackery, perhaps even the mother's suicide, which took place several years before the play begins. However, the crimes referred to in the title are crimes of emotional offenses to the self as well as to others, such as Lenny's jealousy of her sister Meg, also Meg's rejection of Doc Porter, a local man who married someone else and her subsequent attempts to restore the affair. Other crimes of passion include Meg's lies to her grandfather about her successful singing career, Babe's and Meg's forgetting Lenny's highly important thirtieth birthday, Lenny's spurning a would-be fiancé in favor of staying at home to serve old grandfather and cousin Chick ill-treatment of all the Magrath sisters.

A closer examination discloses that another sort of crimes has been committed, not by the perplexed on-stage women, but by the powerful off-stage men. One off-stage male who figured prominently into the lives of the sisters is their father who deserted their mother when they were children. They remember his hateful smile, and Meg despises his white teeth. Babe holds him responsible for their mother's suicide and for the death of the yellow cat, the mother hung beside herself: "It was after [our father] left that she started spending whole days just setting there and smoking on the back porch steps. She'd sling her ashes down onto the different bugs and ants that'd passing by" (p. 25). His absence led them to move from Vicksburg to Hazlehurst, Mississippi to live with another patriarchal off-stage figure - their maternal grandfather who had a disastrous influence on their lives. Rosefeldt (1995) argues that this absent surrogate father controls the progress of the plot and his dying fits consumes a large 
portion of the play. As the plot unfolds, the audience becomes increasingly aware of the sisters' submissive dependence on him and the damaging role he plays in shaping their lives. Discussing their younger sister's wedding, Lenny reminds Meg:

Old Granddaddy used to call Babe, his dancing sugarplum. Why remember how proud and happy he was the day she married Zackery.... He remarked how Babe was gonna skyrocket right to the heights of Hazlehurst society. And how Zackery was just the man for her whether she knew it or not. (p. 19)

Babe seems to have practically no say in selecting her husband; she was just eighteen. When Meg and Lenny look at their younger sister's wedding photo, Lenny exclaims that Babe seems almost twelve years old. Meg asks her whether she had been happy at that time, Babe only remembers being "drunk on champagne punch" (p. 49). The argument over Meg's lies about having a bright singing career reveals that Old Granddaddy too has made up this decision for her:

Meg. ... I hate myself when I lie for that old man. I do. I feel so weak. And I have to go and do at least three or four things that I know he'd despise just to get even with that miserable, old, bossy man.

Lenny. Oh, Meg, please don't talk so about old granddaddy! It sounds so ungrateful! Why he went out of his way to make us, to treat us like were his own children. All he ever wanted the best for us. That's all he ever wanted.

Meg. Well, I guess it was; but sometimes I wonder what we wanted. (p. 48)

Whereas Babe has been pushed out of family home to play the role of a wealthy man's wife and gain social mobility, Meg has been urged to find fame and fortune in Hollywood. Now she realizes that after all she pursued the singing profession only to satisfy Old Granddaddy. Lenny's case is more problematic. The most obvious object of her desire is to marry Charlie Hill, the man she claims to have left because of her immature ovaries. Lenny tells her sisters that she has abandoned Charlie before informing him that she is unable to have children, because she wanted to avoid the intolerable feeling of being abandoned. Her only choice is to remain at home to serve her grandfather. Laughlin (1986) points out that the sisters are in a sense victims of the restrictive models of life offered to them by old granddaddy in particular and the patriarchal society in general. The relationship between the women's options and the workings of their loaned desires not only exposes the patriarchal wickedness, but also explains the devastating nature of the women's choices.

In effect, the sisters have tried to carry out their grandfather's dreams. He has filled them with debilitating images of success, which drive them to adopt self-damaging lifestyles. Zackery, the prosperous lawyer and the richest man in town, whom he believed to be the right husband for Babe, the youngest and most beautiful sister, turns out to be a callous abusive man. Denying her injuries, Babe seeks solace in her friendship with a fourteen- year-old-black boy. She only cuts loose when Zackery strikes the boy badly. Taken aback by her husband's ruthless racism, she first thinks of committing suicide, as her mother did long ago, and then she rejects suicide by shooting the source of her torture, Zackery, in the belly. Facing legal charges and Zackery's subsequent plans to commit her to a mental asylum, she shrinks back to suicide as the only accessible action in a society sanctioning violence against women. Zackery is threateningly certain that psychiatric centers are prepared to punish and reform women who defy men's supremacy. Consequently, Babe comically tries to hang and then suffocate herself in a gas oven. Pursuing the path old granddaddy has decided for her left her baffled and hopeless.

Granddaddy's plans for the middle sister, Meg, also led her astray. He implanted in her mind that she could be a Hollywood star. However, unable to attain success, she ends up working for a dog food company. Since her grandfather's dream never comes true, she hides the truth of her minor career by providing her family with exaggerated lies about her artistic achievements. She has to create a false identity to live up to the expectations of a father figure and this eventually drives her to the edge of madness. She partially loses her singing voice and accomplishes only a nervous breakdown.

Like Babe and Meg, Lenny too is acting out Old Granddaddy's image of what she should be. He told her that the man would not marry her because she could not have children. He made her feel insecure because of her "shrunken ovary" (p. 34), so she stopped seeing the man because of old grandpa. Meg accuses Lenny of living out her life as Old Granddaddy's nursemaid. She tries to convince her that she can have a romantic attachment and that the old man is the only one who thinks otherwise to keep her as his exclusive attendant. Nevertheless, Lenny is sure that he always wanted to see them happy. Thus, the sisters were ensnared in an uncertain relationship with their dying substitute father who imposed on them his petty materialistic ideals and whose efforts to manufacture happy lives for them in line with the notions of submissive southern femininity left them miserable and debilitated.

The way he defectively influenced them can be seen when he bought them banana splits for breakfast on the day of 
their mother's funeral. Meg recalls that granddad's attempt to keep them happy caused them all to get sick, "turning green and throwing up in the flower arrangements" (p. 50). Morrow (1988) contends that by giving the newly orphaned sisters banana splits for breakfast, he very early established a harmful oral pattern that taught them to repress grief and anger, to avoid problems rather than face them thus repeating the self-destructive behavior that drove their mother to suicide. Meg unconsciously reproduces her mother's denial of pain and anger by smoking cigarettes, which gives her a false sense of power and control over her destiny. Babe reveals that things have been hard for her middle sister, "after all, she is the one who found out [the dead body] of mama" (p. 45). Trying to harden herself against the tragedies of life, Meg, Babe recalls, used to go over the library and would spend all her time reading and looking through the sickening pictures of an old book about skin diseases. In the same way, she would spend hours forcing herself to look at a poster of crippled children stuck up in a drug store window, then she would buy "a double-scoop ice cream cone and eat it all down," only to prove to her younger sister that she was able to endure hardships of any kind (p. 46). Babe shoots her husband, and then drinks greedily three glasses of lemonade until she becomes distended. When Lenny becomes packed with old granddaddy's advice, she says, "I'm gonna vomit" (p. 81). Aborting their rage and turning it inward, the mother and her daughters follow an upsetting demeanor to obtain a false sense of control and strength in a hostile environment. Thompson (1992) further remarks that obsessive eating and drinking alleviates their unhealthy withdrawal from existence consequently their worst fears become allied with further rejection and loneliness.

An important parallel between Henley and Shange's works is that the women in both plays have already embarked on a journey of healing when the plays start and their recoveries have stemmed from very heartbreaking actions. Reassessing harsh memories stimulates this thorny process towards healing, self-awareness and, finally, self-assertion. After Sixteen years, the Magrath sisters, realizes the absurdity of denying their heartache by feeding the stomachs. Meg's nervous breakdown is a signal of health for she has been living on sweet illusions, but since that time, she has been unable to read letters from home because they arouse splitting pains in her chest, pains that prove that she cares. By shooting Zackery, Babe revolts against Old Granddaddy's control and forces herself and her sisters to deal with the legacy of their mother who committed suicide in loneliness and despair for being abandoned by her husband. "Suddenly, for some reason, I thought about Mama....how she'd hang herself. And here I was about ready to shoot myself" (p. 37). Then, in a moment of enlightenment, however, she realizes that "I didn't want to kill myself! And she... probably didn't want to kill herself, I wanted to kill Zackary not myself cause I ...wanted to live" (p. 37). Zackary's menace to send her to a mental asylum incites her deepest fear- that she is mad like her mother. Meg, who convinces her that she is not alone, that she really wants to live to celebrate Lenny's birthday, rescues her. Lenny's thirtieth birthday wish is that "old granddaddy would be put out of his pain" (p. 62), a euphemistic expression for wishing him to die in peace, though she feels guilty when he goes into a comma. Her chase of cousin Chick up a tree with a broom indicates her firm resolve to protect her sisters from the offences of a despicable social conformist who often criticizes their actions. Also rebelling against Old Granddaddy, Meg states, "I sang right up into the trees! But not for Old Granddaddy. None of it was to please him" (p. 64). Then she declares defiantly, "He's just gonna have to take me as I am and if that sends him into a comma, that's just too damn bad" (p. 65). Ironically, he has just been into a comma and Meg's line causes hysterical laughter. Rosefeldt (1995) maintains that the scene represents a fine line between comedy and horror and demonstrates the growing rebellion against the absent father figure.

The play ends with a collective scene in the three sisters gather and Lenny makes a birthday wish as she does at the beginning, but this time she is not alone, and she has a birthday cake instead of a stale cookie. Her final wish is a vision of the three sisters smiling and laughing together signifying that they realize the significance of their sisterly unity and shared aims to mend their shabby lives. As they get together to celebrate Lenny's birthday, they finally feel freed from the negative domination of granddaddy who symbolizes what Laughlin(1986) terms "the mediating patriarchal forces" in a tradition-bound society against which the women rebel. Meg can sing again, but not to please him, and she can love and care again. Babe is free of Zackery's legal charges with the help of a young lawyer, Barnette Lloyd, with whom she seems to start a new and more fruitful relationship. Lenny talks to her ex-fiancé Charlie Hill and she no longer has to play the role of a substitute grandmother nor feel doubtful about her adequacy to have a future husband. Instead of eating banana splits to relieve their torment, they tear into Lenny's birthday cake, an act suggesting their "rejection of convention," as Mapp (2002) points out, to rejoice their newly renovated selves.

\subsection{For Colored Girls Who Have Considered Suicide / When the Rainbow Is Enuf}

Shange's for colored girls, is a choreopoem in which seven women sing, dance, speak about their desperate lives and celebrate the rise of consciousness and unity of the black females. The play is divided into twenty episodes/poems; each one of them represents the story of a black girl striving to escape the abuses and restrictions 
of an oppressive male-dominated society. As Henley's females, the black women in Shange's play have to confront their pathetic past to be able to come to terms with their disordered lives. In their appalling stories, they mourn over their wounds, but they also exhibits their ability to go on in the world. Black men often inflict the misery of these women; consequently, some reviewers, for instance Vandergrift (1994), think that the thematic emphasis is constantly placed on blatant brutality of black men. However, many women, not just of color, identify with Shange's poems and admire them as a festivity of the solidarity of women and the power they obtain from each other.

The play's title refers to the double burden of black women who feel imprisoned by a society that constrains their lives because of their sex and color. As a writer, Shange is committed to women and maintains in her interview with Lester (1990) that "everything I write and have written comes from being a woman-centered person" (p. 726). In addition, the title emphasizes a significant thematic parallel between Shange's play and Henley's i.e., suffering women's considering, attempting or committing suicide mainly because of feeling powerless in aggressive surroundings. Rushing (1981) claims that the play is deeply rooted in Shange's own life who attempted suicide after separating from her law-student husband at the age of nineteen. The women in the play, like their creator, belong to black middle and upper middle-classes for none of them complains of severe poverty or non-employment. He argues that the suicide of such women often results from a negative self-image, low self-esteem and feelings of isolation and rejection mostly due to failed social relationships. This perfectly applies to the white suicidal women in Henley's play, Babe and her mother, and suggests the bond of feminist agony regardless of color.

Rushing (1981) criticizes Shange's total disregard of white responsibility for the dilemma of black people in general, and black women in particular. The play does not refer to past and present tensions between the blacks and whites in America owing to white racism and capitalism. He also criticizes the play's glorification of individual happiness which, though typically American, but is at odds with the Afro-American concept of the salvation and regeneration of the black people. On the other hand, Brown-Guillory (1987) points out that though the images in Shange's play do not represent the majority of black people, but "no two or three writers can or should have to try," and "her work presents a vital slice of life" (p. 239). In addition, she refers to the universal appeal of the play for though the play is by, about, and for blacks, but it is also for women worldwide who need to know that they are not alone in grief. She further indicates that the plays of Shange, like those of Alice Childress and Lorraine

Hansberry, have created positive images of both black men and women that dismiss the traditional minstrel stereotypes of the content slave, the tragic mulatto, the comic Negro or the singing faithful servant. One creative image that dominates their plays is "the evolving black woman," who attempts to assert her full humanity as a colored woman and through her resiliency and self-respect forces the others around to recognize her maturity and independence (p. 234).

The twenty poems, delivered by black women, identified only by the rainbow colors of their dresses, record the black woman progress from coming face to face with the pains of betrayal, abandonment, rape and abortion to achieving a true sense of identity, and establishing a quasi-spiritual community with her peers. As Young-Minor (1994) claims, the play gives to many black girls what the "bildungsron" tradition provided for the European audiences: a chance to explore development from adolescence to maturity but in an Afro-American context (p. 98). By not giving names or specifying their individual features, other than the color, Shange underlines the symbolic nature of her characters who become representatives of all women, thus stressing the universality of women's plight. At the end, the rainbow all at once becomes a metaphor for the ethereal alliance of women that enables them to find out their innate beauty and power and realize their merit as human beings. The women in for the colored girls have been disillusioned by men and are no longer willing to play the role of the defeated creatures by living with men who brutally abuse them and appreciate neither their love nor their humility. They fight back after being repeatedly hurt and they are now able to fight to mend their lives.

Their desire to dance opposes their feeling of suffering - dance and music being signs of their audacity to project their lives in the world with grace, to seek warm relations with others, to delight in the enormous potentiality of life. According to Waxman (1997) "inherent in the act of dancing ...are, in varying degrees, self- affirmation, eroticism, spiritual renewal, and communal bondage, [all of which suggest] dance's ability to heal the mind and body's split" (p. 91). In particular, Shange's uses dance or expressive movement as a vehicle to discover and celebrate the female black body as well as to achieve the unity of the body and mind. In addition, for Shange's characters, dance provides a relief from emotional turmoil and is a means for survival: "We gotta dance to keep from cryin/ we gotta dance to keep from dyin" (p. 29). Near the end, the stage directions indicate the unanimity of women when their collective dance "reaches a climax and all the ladies fall out tired, but full of life and togetherness" (p. 63). 
Music, dance, movement as well as other forms of non-verbal devices, are central to Shange's style because verbal language, a device of the white patriarchy, fails blacks in American culture. In order to sing a black woman's song, Shange must reconstruct the language of her distinctive sensibility. Shange's poems disregard regular syntax, spelling and punctuation and her spoken diction is delicately knitted with music and movement. Shange actually calls for forming a woman's aesthetic that discards the Western notion, which split body and mind, all for an Afro-oriented ideal in which body, mind and spirit are one in order to discover, cure and liberate the female self. Brown (1996) asserts that by emphasizing the body and animating it with movement, dance becomes an instrument by which Shange can "write and rite" (i.e., ritualize) the black woman's body, healing its historical dismemberment due to long racial and sexual oppression (p. 150). The choreopoem is thus a perfectly proper genre to contain all of these senses and allows Shange to convey a communal experience and restore the Afro-American female identity.

The lady in brown is the only character who supposedly does not represent any of the colors of the rainbow, nevertheless, brown is the color of the Afro-American skin that distinguishes the Afro- American self. She opens the play with a song stating the black woman's need to communicate her experience in song and story and to confront the injustices she suffered long to recognize her worth as a human being:

somebody/anybody sing
a black girls song
bring her out
to know herself
to know god
but sing her rhythm
crain/struggle/hardness
sing her song of life
she's been dead so long
closed in silence so long
she doesn't know the sound
of her voice her indefinite beauty
sing a righteous gospel
let her be born... (pp. 18-19)

The opening poem sets the tone for what is expected to come to light in the show. Indeed the first poem serves as a precursor of the final climatic moment of rebirth when the black characters will be well aware of themselves and of their ability to participate fully in the life as autonomous forceful beings.

After the opening declaration, other black women appear on the stage to announce that they come together to weave stories "for the colored girls who have considered suicide when the rainbow is enuf." Their stories specify the desperate and oppressive situations they have gone through, confirm the depth of their desolation and stimulate them to battle for more expectant scopes. These stories function as confessions that not only free them but also free those who listen to their tales. They suggest a road towards spiritual liberation and wholeness by challenging various aspects of black female reality. Young-Minor (1994) maintains that these women are in essence "performers-preachers" using the stage as a platform to change ideology and behavior (p. 112).

The early poems in the play generate a cheerful atmosphere for being young and alive. In "graduation nite," Shange recognizes that adolescent sexual awakening is empowering and pleasurable for a female coming to adulthood. Sexuality itself is a female life force granted by Mother Nature that needs not to be obscured; rather it should be celebrated. The following poem, "now i love somebody more than," tells the story of the lady in blue's adolescent attraction to the Caribbean beats of a Puerto Rican musician, Willi Collen. The poem as a whole is joyful; nonetheless, it has its solemn moments, including allusions to black self-hatred and color caste systems. Beginning with the first "ola" and moving through lively accounts of her dancing, the poem is an invocation to summon the spirit of music and dance that brings much delight to the colored girl's life.

In the next poem, "no assistance," the lady in red voices her righteous rage for loving a man who showed no gratitude for her affection and with whom she found no "assistance" or "guidance" (p. 27). During their relationship, she felt tormented by a mixed sense of loneliness and humiliation for "not being wanted/ when $\mathrm{i}$ want to be wanted" (p. 28). After " 8 months//2 wks\&// a day" (p. 27), she concluded that she did not have to waste her 
precious life with the likes of this insensitive and uncaring man. Developing more strength and self-confidence, she ended up the relationship as an independent woman free of exploitation and degradation.

In "abortion cycle \#1," Shange transmits a woman's vulnerability during unlawful abortion. The poem begins with four women screaming, "eyes," "mice," "womb," "nobody" (p. 35). The rest of the poem spoken by the lady in blue is a set of interwoven images which incite passions of pain, disgust, fear, shame and death. She felt like something huge and powerful was inside her womb, as if death was coming out of all her body holes. In sharing her story with other distraught women, the lady in blue achieves a sort of emotional relief through which she can start throwing away with her disgrace and loneliness.

In "latent rapists," all the women contribute to the poem suggesting that this not an isolated story. They verbalize the prevailing biased views of the male-dominated society with regard to a rape victim: "if you know him, you must have wanted it," "are you sure you didnt suggest," "had you been drinkin," "a rapist is always a stranger" (p. 31). What these women realize is that "we are betrayed by men who know us" (p. 33). In this poem, Shange draws attention to a social and legal problem in American biased culture that deepen the persecution of black women.

The lady in purple narrates the story of Sechita, who represents black beauty and pride in an adverse environment. A carnival travelling dancer in the time of post-Civil War, she is also, "the Egyptian goddess of creativity... threw her heavy hair in a coil over her neck/ sechita...spread crimson oil over her cheeks/waxed her eyebrows" (p. 38). Following a wrestling match, she finds the courage to defy bravely "the redneck whoops... in the cracker nite" (pp. 38-39). The white men degraded her by throwing gold pieces between her legs, but she "kicked viciously thru the nite/ catching stars between her toes" (p. 39). Shange indicates in the introduction to the play that though the poem is set in the past, Sechita could be a contemporary young woman down the Forty-second street or around the corner from Broadway lights where the play has had many successful runs.

Racial anxiety associates with gender in "toussaint l'overture," told by the lady in brown in the first person. When she was young she won a prize in a children contest for reading, but the prize was later taken away from her because the book she read on Toussaint was taken from the adult reading room. She had to read only the books placed in the children's room: "in the children's room/only pioneer girls \& magic rabbits \& big city white boys" (p. 40). The narrator became bewildered and frustrated for Toussaint, the Haitian nationalist, became her ideal hero, not the white authors and white characters usually introduced to black students by the U.S. educational system as the only reality. He refused to be treated as a slave, spoke French and "didn't low no white man tell him nothing/ no napoleon/ not maximillien/ not robespierre (p. 40). She decided to run away from her integrated milieu to find Toussaint in a spiritual search for self. On the way, she met a young black boy, also named Toussaint, who asserts, "I don't take no stuff from no white folks" (p. 44). The boy Toussaint Jones who spoke English and ate apples by the St. Louis River then replaced the Haitian L'Overture. Toussaint Jones is the only positive male character in the play, and with the young lady in brown, they represent the rising black men and women who struggled against racial prejudice for black equality and civil rights during the fifties and the sixties of the twentieth century and managed finally to change the U.S. social order.

"toussaint l'overture," along with "now i love somebody more than," are described by Shange as "journey poems" in which young girls run away with dreams of discovery (p. 3). The poems introduce the girls to other kinds of people and other worlds. They introduce them to "adventure, and kindness, and cruelty... cruelty that we usually think we face alone, but we don't" (p. 3). The girls discover that "by sharing with each other, they find the strength to go on" (p. 3).

Shange's examination of black women's strength and oppression continues. In the next poem, "i useta live in the world," the lady in blue contrasts the enormity of her previous life in Africa with her dull life in Harlem neighborhood where "my ankles are coated in grey//filth form the puddle neath the hydrant" (p. 50). There, she feels hopeless and alienated and is subject to constant physical and sexual attacks from men and even boys who comfort their broken self-esteem by abusing women. As a woman, she suffers from utter disgrace, for Harlem, with all its images of urban dirt, captivity, estrangement and masculine brutality, destroys the possibility of the black woman's freedom in the city. To her utter misery, she realizes that in order to stay alive in such a vicious, threatening setting, she must be violent: "I can't be nice to nobody/ nice is such a rip-off regular beauty \& a smile in the street is just a set-up" (pp. 52-53).

In "pyramid," the lady in purple deals with how women bargain their sisterly bond to live romantic illusions with essentially cruel and manipulative men, thus contributing to their own humiliation. At first three women were close friends: "one laugh// one music// one flowered shawl// knotted on each neck" (p. 53). However, once the man comes in their way they split. With the course of time, they discovered that they were loved and betrayed by the same man: "the rose // she left by his pillow// she found on her friend's desk" (p. 55). She confronted her friend, 
then both reconciled and went to confront him where "he was wit another woman" (p. 55). However, he was callously indifferent to them and "smiled a lot" (p. 56). The friends consoled each other and became close friends once again with an awareness that the most tying bond was their sisterly care and love:

she held her head on her lap/

the laps of her sisters soakin up tears/

od between them/

love between them/love

like sisters. (p. 56)

In "somebody almost waked wid alla my stuff," Shange expresses the black woman's resolution not to demean herself to satisfy a man's ego. The lady in green sums up her story with the image of thievery. She was in love with a man who attempted to rob her off all the valuable things she had: her youth, her vitality, and her ability to feel affection for others. She lists some of her precious belongings that stand for her unique personality: her "rhythms", her "voice", her "memories" and her "innocence" (p. 64). Apparently, she did not put up with humiliation and self-hatred after he had left her. At the worst moments of her life, she was "spattered wit mud and city rain" (p. 65). Soon she built up a positive self-awareness and turned her anger at the man who did not deserve what she had to offer. She forcefully announces her determination to reclaim her shattered self-esteem: "i want my stuff back... i want my own things" (p. 65). Christ (1980) argues that the process of counting her "stuff" is healing because it affirms her whole self, not just the self that has been preened and coddled to meet male consent.

In a humorous episode, the women repeat some of men's ridiculous apologies for their offensive demeanor. The lady in blue stresses the intolerable injuries caused to women by men's indifference and infidelity: "you were always inconsistent// doin somethin \& then bein sorry// beatin my heart to death" (p. 67). She also sums up the women's joint decision not to endure more abuses from men nor to continue playing the role of female submissiveness: "one thing I don't need// iz any more apologies ...you can keep yrs...i am simply tired of the collection" (p. 67).

The last and most appalling narrative, "a nite wit beau willi brown," is told by the lady in red. Beau Willi, a disturbed veteran, was left by Crystal, the mother of their two children after enduring his physical and verbal violence for years. She also managed to have a court order to prevent him from hurting her and the children. Willi, who is described as "crazy as hell" (p. 80), kept coming to beg Crystal to return to him, to be able to receive veterans' allowances and stop working the petty job as a taxi driver, but she adamantly refused. On his last visit, he tricked her so she allowed him to hold the two children, Naomi and Kawme. He then opened the fifth-floor window and dangled the children out threatening to drop them unless she publically promised to go back to him. The lady in red relives the tragedy by shifting from third person to first person narrator: "i stood by beau in the window wit naomi reaching for // me \& kawme screamin mommy mommy from the // fifth storey// but / I cd only whisper// \& he dropped'em" (p. 84).

Crystal's personal misfortune becomes an epitome of all female tragedy. As a woman, she has to suffer from vengeful brutality to achieve full autonomy in suffocating surroundings. Hamilton explains that Crystal's voice fails her because she has no voice in her relationship nor in the world. Had she been allowed to have a voice, she might have stopped Willi... but "there waz no air," a refrain she repeats to symbolize the historical suppression of black feminine identity. Flowers (1981) argues that by dropping his children, Willi, literally and symbolically, not only commits murder but also he commits suicide because he kills the hope of both male and female black identity represented by his offspring.

The emotional intensity and the horror of the story make the women sympathize with Crystal /the lady in red. Therefore, each woman understands what she means when she cries, "i was missin somthin" (p. 84). They spontaneously join her in a colorful choir in which each woman has a distinct voice, yet all of them create one fervent synchronized beat. Each of them responds in turn: "somethin so important," "something promised" (p. 84). The lady in blue declares that what is missing is "not a man" (p. 86), and the lady in purple says it is neither her mother nor motherhood. Hence, Shange's women are far more radical feminists than Henley's women are. The Magrath sisters' ultimate vision of redemption incorporates other men. That is why a feminist critic like Haedicke (1993) laments Henley's "regressive" drama which offers at best "feminist hesitations rather than feminist politics" (pp. 83, 86).

Eventually, the lady in blue specifies the thing they need in their lives - the road to female survival: "a lay on of hands" (p. 84). The other women passionately agree that this ancient ritual, practiced in some black churches, has great curative and emancipating effects on the divided female self: "strong," "cool," "movin," "somethin free," 
"makin me whole," "pure," and "all the gods comin into me// layin open to myself" (p. 85). Their words illustrate the inspiring sensation felt by the injured through the sympathetic tap of the hands of other members of the community. The laying on of hands suggests that no one of the women is alone and that other women will protect her life and health. Only the hands of her sisters can assist her to overcome utter misery and despair and reach the spheres of physical, mental and spiritual wholeness.

Crystal/ the lady in red reveals that she has actually considered suicide after the disaster of losing her children: "who was_missin what i was_missin/i wanted to jump outta my bones $\&$ be done wit myself (p. 87). Nevertheless, with other women's help, Crystal is able to move out of existential void, to have the spiritual power to overcome the destructive impulse and to reconstruct a renewed sense of being in the universe:

i waz cold / i waz burnin up/ a child \& endlessly / weaving garments for the moon// wit my tears i found god in myself and I loved her fiercely. (p. 87)

Mitchell (1984) explains that through the images of hot and cold, Shange evokes the fever associated with childhood thus referring to the process of the women's rebirth, whereas she suggests female affinity and understanding by assembling all the celestial powers together as a binding and healing whole. The god she discovers within herself refers to a unifying sacred conviction through which she and her fellow women come to understand their potential power to survive and create their own reality.

All the women gently say again, "I found god in myself/ I loved her," and as the stage directions indicate the lines soon heighten to an ecstatic song of happiness shared among themselves, then with the audience. Finally, they "enter into a closed tight circle," (p. 88) suggestive of feminine commonality in their newly discovered utopia. All of them at last move to "the ends of their rainbows" (p. 88) rising above silence and suffering in their efforts to attain a positive sense of new black womanhood which places power and beauty in the female self.

\section{Conclusion}

Beth Henley and Notzake Shange are two contemporary women playwrights who explore the process through which American female identity has been badly affected by an over-riding patriarchal society. Though they belong to different cultures, Anglo-American and African-American, and each has her unique dramatic technique, both dramatists demonstrate the bond of agony among women in the U.S. modern culture due to a wide-range of negative male attitudes and practices. Henley incorporates weird comedy into her Crimes of The Heart, a domestic drama of grief, frustration and loneliness. Her Magrath sisters are essentially tormented, self-destructive females whose lives and existence have been wrought by their male family members and the sexist ideals of the small U.S. southern towns. On the other hand, Shange abandons the Euro-grounded theatrical form in her play, for the colored girls throwing out conventional characterization and plot and innovates a nonlinear choreopoem, a dramatic structure primarily consisting of a series of poetic monologues coalesced with dance, movement, Afro-American rhythms and music. In these poetic episodes, the women perform and share experiences and stories to express the twofold negation and pain felt by the black women for being abused by white society and black men. The major parallel between the two plays is that only after the women confront their gloomy past that they are able to overcome their misery, to realize the devastating cultural patterns which contribute to their debasement and eventually to become fully aware of their prospective as worthy and autonomous human beings. In addition, both plays envision women's survival through achieving an awakened sense of female solidarity thus creating a sisterly bond of mutual trust, affection and devotion among women that allows their rebirth out of despair and nothingness.

\section{References}

Brown, E. B. (1996). Shackles on a Writer's Pen: Dialogism in Plays by Alice Childress, Lorraine Adrienne Kennedy and Ntozake Shange (Unpublished doctoral dissertation). North Carolina University, U.S.A.

Brown-Guillory, E. (1987). Black Women Playwrights: Exorcising Myth. Phylon, 48(3), 229-239. https://dx.doi.org/10.2307/274383

Christ, C. P. (1980). Diving Deep and Surfacing Women Writers on Spiritual Quest (pp. 97-118). Boston: Beacon Press. Retrieved from http://go.galegroup.com.mutex.gmu.edu/ps/i.do?id=GALE\%7CH1100003203\&v=2.1\&u=viva_gmu\&it=r\& $\mathrm{p}=\mathrm{LitRC} \& \mathrm{sw}=\mathrm{w}$

Demastes, W. W. (1986). American New Realism in the 80s: Fuller, Henley Norman, Rabe, Mamet (Unpublished doctoral dissertation). University of Wisconsin, Madison, U.S.A.

Flowers, S. H. (1981). Colored Girls: Textbook for the Eighties. Black American Literature Forum, 15(2), 51-54. https://doi.org/10.2307/2904081 
Gupton, J. L. (2002). Un-ruling the Woman: Comedy and the Plays of Beth Henley and Rebecca Gilman. In R. L. McDonald, \& L. R. Paige (Eds.), Southern Women Playwrights: W New Essays in Literary History and Criticism (pp. 124-138). Tuscaloosa: University of Alabama Press. Retrieved from http://go.galegroup.com.mutex.gmu.edu/ps/i.do?id=GALE\%7CH1100083180\&v=2.1\&u=viva_gmu\&it=r\& $\mathrm{p}=\mathrm{LitRC} \& \mathrm{sw}=\mathrm{w}$

Hamilton, C. L. (n. d.). An overview of for colored girls who have considered Suicide/when the rainbow is enuf. Drama for Students. Detroit: Gale.

Haedicke, J. V. (1993). A Population and Theatre at Risk: Battered Women in Henley's Crimes of the Heart and Sheppard's A Lie of the Mind. Modern Drama, 36(1), 83-95. https://doi.org/10.3138/md.36.1.83

Henley, B. (1982). Crimes of the Heart. New York: Dramatists Play Service.

Laughlin, K. L. (1986). Criminality, Desire and Community: A Feminist Approach to Beth Henley's Crimes of the Heart. Women and Performance, 3(1), 35-51. https://doi.org/10.1080/07407708608571094

Lester, N. A. (1990). At the Hearts of Shange's Feminism: An Interview. Black America Literature Forum, 24(4), 717-730. https://doi.org/10.2307/3041798

Mapp, L. G. (2002). Lessons from the Past: Loss and Redemption in the Early Plays of Beth Henley. In J. Fesmire (Ed.), Beth Henley: A Casebook (pp. 32-41). New York: Routledge. Retrieved from http://go.galegroup.com.mutex.gmu.edu/ps/i.do?id=GALE\%7CH1100083178\&v=2.1\&u=viva_gmu\&it=r\& $\mathrm{p}=\mathrm{LitRC} \& \mathrm{sw}=\mathrm{w}$

Mitchell, C. (1984). A Laying on Hands: Transcending the City in Ntozake Shange's for colored girls who have considered suicide / when the rainbow is enuf. In S. M. Squier (Ed.), Women Writers and the City: Essays in Feminist Literary Criticism (pp. 230-148). Knoxville: University of Tennessee Press. Retrieved from http://go.galegroup.com.mutex.gmu.edu/ps/i.do?id=GALE\%7CH1100019809\&v=2.1\&u=viva_gmu\&it=r\& $\mathrm{p}=\mathrm{LitRC} \& \mathrm{sw}=\mathrm{w}$

Morrow, L. (1988). Orality and Identity in night Mother and Crimes of the Heart. Studies in American Drama 1945-present, $\quad 3, \quad 23-39 . \quad$ Retrieved from http://go.galegroup.com.mutex.gmu.edu/ps/i.do=GALE\%7CH1100083169\&v=2.1\&u=viva_gmu\&it=r\&p= LitRC\&sw $=\mathrm{W}$

Rosefeldt, P. (1995). Trapped in the Father's Dying World: Beth Henley's Crimes of the Heart and Chekhov's The Three Sisters. The Absent Father in Modern Drama (pp. 75-82). Switzerland: Peter Lang. Retrieved from http://go.galegroup.com.mutex.gmu.edu/ps/i.do?id=GALE\%7CH1420035103\&v=2.1\&u=viva_gmu\&it=r\& $\mathrm{p}=\mathrm{LitRC} \& \mathrm{sw}=\mathrm{w}$

Rushing, A. B. (1981). For Colored Girls, Suicide or Struggle. The Massachusett Review, 22(3), 539-550. Retrieved from http://go.galegroup.com.mutex.gmu.edu/ps/i.do?id=GALE\%7CH1100003199\&v=2.1\&u=viva_gmu\&it=r\& $\mathrm{p}=\mathrm{LitRC} \& \mathrm{sw}=\mathrm{w}$

Shange, N. (2010). For colored girls who have considered suicide / when the rainbow is enuf. Scribner: New York.

Shange, N. (1979). Uncovered losses/ black theatre traditions. The Black Scholar, 10(10), 7-9. https://doi.org/10.1080/00064246.1979.11412714

Thompson, L. (1992). Feeding the Hungry Heart: Food in Beth Henley's Crimes of the Heart. Southern Quarterly, 30(2-3), 99-102. Retrieved from http://go.galegroup.com.mutex.gmu.edu/ps/i.do?id=GALE\%7CH1100083172\&v=2.1\&u=viva_gmu\&it=r\& $\mathrm{p}=\mathrm{LitRC} \& \mathrm{sw}=\mathrm{w}$

Vandergrift, K. E. (1994). Ntozake Shange: Overview. In L. S. Berger (Ed.), Twentieth-Century Young Adult Writers. Detroit: St. James Press. Retrieved from http://go.galegroup.com.mutex.gmu.edu/ps/i.do?id=GALE\%7CH1420007292\&v=2.1\&u=viva_gmu\&it=r\& $\mathrm{p}=\mathrm{LitRC} \& \mathrm{sw}=\mathrm{w}$

Waxman, B. F. (1994). Dancing out of Form, Dancing into Self: Genre and Metaphor in Marshall, Shange and Walker. Melus, 19(3), 91-106. https://doi.org/10.2307/467874

Young-Minor, E. A. (1997). To Redeem her Body: Performing Womanist Liberation (Unpublished doctoral dissertation). Bowling Green State University, U.S.A. 


\section{Copyrights}

Copyright for this article is retained by the author(s), with first publication rights granted to the journal.

This is an open-access article distributed under the terms and conditions of the Creative Commons Attribution license (http://creativecommons.org/licenses/by/4.0/). 